\title{
Assessment of Undiscovered Conventional Oil and Gas Resources of the Cooper and Eromanga Basins, Australia, 2016
}

Using a geology-based assessment methodology, the U.S. Geological Survey estimated mean conventional resources of 68 million barrels of oil and 964 billion cubic feet of gas in the Cooper and Eromanga Basins of Australia.

\section{Introduction}

The U.S. Geological Survey quantitatively assessed the potential for undiscovered, technically recoverable conventional oil and gas resources in the Cooper and Eromanga Basins of Australia (fig. 1) as part of an effort to assess priority geologic provinces of the world. By Australian convention, a basin represents an unconformity-bounded set of genetically related strata and can be vertically stacked. Thus, the Warburton (CambrianDevonian), Cooper (Permian-Triassic), Eromanga (JurassicCretaceous), and Lake Eyre (Tertiary) Basins are stacked (Menpes and Hill, 2012), with each succeeding basin areally larger than the preceding one. For this U.S. Geological Survey assessment, the Eromanga Basin Province encompasses the Cooper and Eromanga Basins. This study assessed the potential for undiscovered conventional oil and gas resources in the Cooper and Eromanga Basins, in which more than 500 conventional oil and gas fields have been discovered since the 1960s (IHS Energy, 2015). Given the exploration maturity, most undiscovered fields are estimated to be small and in stratigraphic or combination structural-stratigraphic traps (Apak and others, 1997).

For the assessment of conventional resources, the

U.S. Geological Survey defined a Cooper-Eromanga Composite Total Petroleum System with Permian and Jurassic coals as the primary source rocks for oil and gas (Boult and others, 1997; Lowe-Young and others, 1997). Five assessment units (AUs) were defined within this composite total petroleum system to encompass oil and gas that were generated largely from coals and migrated and were trapped in Permian through Cretaceous reservoirs. Three AUs were defined within strata of the Cooper Basin and two within the Eromanga Basin. Most of the known gas fields are in the Cooper Basin, whereas most oil fields are in the overlying Eromanga Basin. The assessment input data for the five conventional AUs are shown in table 1.

\section{Undiscovered Resource Summary}

The U.S. Geological Survey quantitatively assessed undiscovered, technically recoverable oil and gas resources in five assessment units within the Cooper and Eromanga Basins (table 2). For undiscovered conventional resources, the mean totals are (1) 68 million barrels of oil (MMBO), with an F95 to F5 range from 39 to $108 \mathrm{MMBO}$; (2) 964 billion cubic feet of gas (BCFG), with an F95 to F5 range from 509 to 1,633 BCFG; and (3) 19 million barrels of natural gas liquids (MMBNGL), with an F95 to F5 range from 9 to 34 MMBNGL.

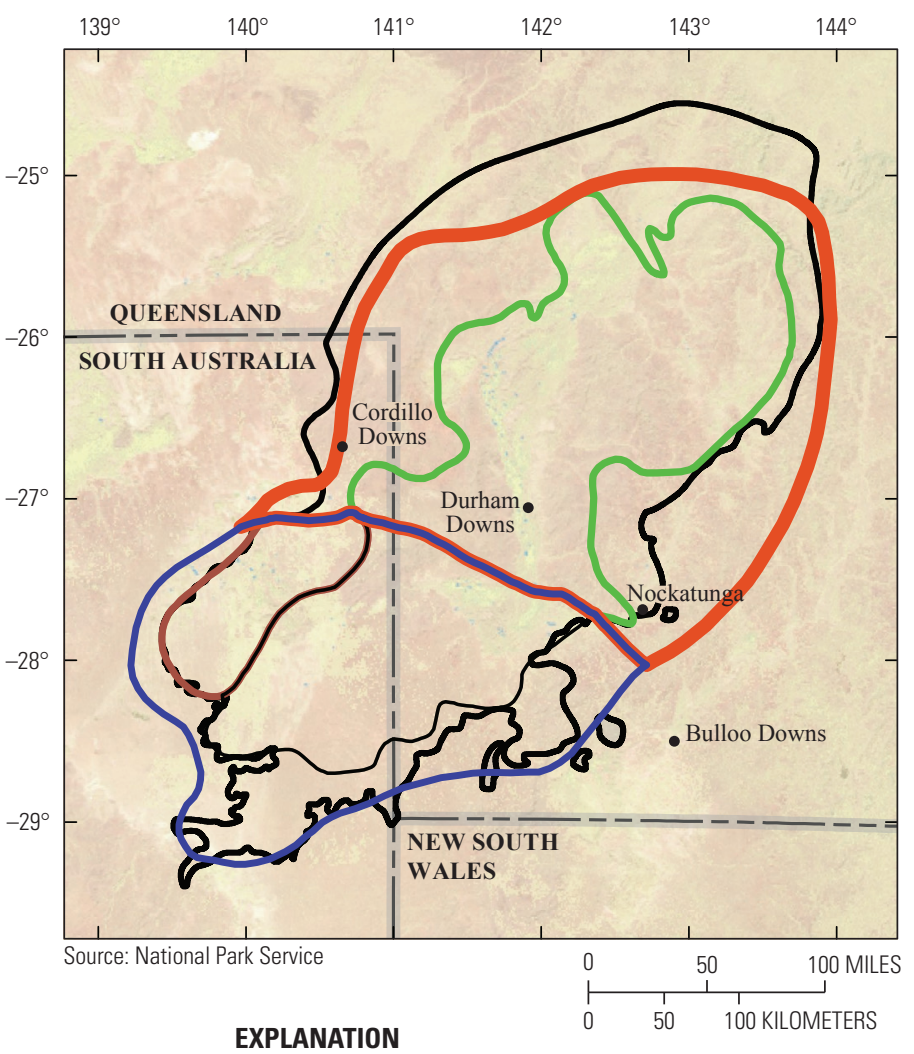

Eromanga Basin Conventional Assessment Units

South Eromanga Basin Mesozoic Conventional Reservoirs AU

North Eromanga Basin Mesozoic Conventional Reservoirs AU

Cooper Basin

Cooper Basin Conventional Assessment Units Greater Nappamerri Trough Permian Conventional Reservoirs AU Greater Patchawarra Trough Permian Conventional Reservoirs AU

Queensland Troughs Permian Conventional Reservoirs AU

Figure 1. Map showing locations of five conventional assessment units in the Eromanga Basin Province, Australia.

Of the mean total conventional oil resource of $68 \mathrm{MMBO}$, $48 \mathrm{MMBO}$ (with an F95 to F5 range from 28 to $75 \mathrm{MMBO}$ ) are predicted to be in the South Eromanga Basin Mesozoic Conventional Reservoirs AU, and $20 \mathrm{MMBO}$ (with an F95 to F5 range from 11 to $33 \mathrm{MMBO}$ ) are in the North Eromanga Basin Mesozoic Conventional Reservoirs AU. About 80 percent of the undiscovered conventional gas resources are predicted to be in the Greater Nappamerri Trough Permian Conventional Reservoirs 
AU (mean of 365 BCFG, with an F95 to F5 range from 226 to $540 \mathrm{BCFG}$ ), Greater Patchawarra Trough Permian Conventional Reservoirs AU (mean of 112 BCFG, with an F95 to F5 range from 40 to $244 \mathrm{BCFG}$ ), and the Queensland Troughs Permian Conventional Reservoirs AU (mean of 290 BCFG, with an F95 to F5 range from 135 to $525 \mathrm{BCFG}$ ).

\section{References Cited}

Apak, S.N., Stuart, W.J., Lemon, N.M., and Wood, G., 1997, Structural evolution of the Permian-Triassic Cooper Basin, Australia-Relation to hydrocarbon trap styles: American Association of Petroleum Geologists Bulletin, v. 81, no. 4, p. 533-555.

Boult, P.J., Ryan, M.J., Michaelsen, B.H., McKirdy, D.M., Tingate, P.R., Lanzilli, Elio, and Kagya, M.L.N., 1997, The Birkhead-Hutton (!) petroleum system of the Gidgealpa area, Eromanga Basin, Australia, in Howes, J.V.V., and Noble, R.A., eds., Proceedings of an International Conference on Petroleum Systems of Southeast Asia and Australasia, Jakarta, Indonesia, May 21-23, 1997: Jakarta, Indonesian Petroleum Association, p. 213-235.

IHS Energy, 2015, International petroleum exploration and production database: Englewood, Colo., IHS Energy.

Lowe-Young, B.S., Mackie, S.I., and Heath, R.S., 1997, The CooperEromanga petroleum system, Australia-Investigation of essential elements and processes, in Howes, J.V.V., and Noble, R.A., eds., Proceedings of an International Conference on Petroleum Systems of Southeast Asia and Australasia, Jakarta, Indonesia, May 21-23, 1997: Jakarta, Indonesian Petroleum Association, p. 199-211.

Menpes, S.A., and Hill, A.J., 2012, Emerging continuous gas plays in the Cooper Basin, South Australia: American Association of Petroleum Geologists Search and Discovery Article \#10422, 7 p.
Table 1. Key assessment input data for conventional assessment units in the Eromanga Basin Province, Australia.

[AU, assessment unit; MMBO, million barrels of oil; BCFG, billion cubic feet of gas. Shading indicates not applicable]

\begin{tabular}{|c|c|c|c|c|}
\hline \multicolumn{5}{|c|}{ Assessment input data } \\
\hline $\begin{array}{l}\text { South Eromanga Basin Mesozoic } \\
\text { Conventional Reservoirs AU }\end{array}$ & Minimum & Median & Maximum & $\begin{array}{l}\text { Calculated } \\
\text { mean }\end{array}$ \\
\hline Number of oil fields & 1 & 50 & 120 & 52 \\
\hline Number of gas fields & 1 & 10 & 30 & 10.6 \\
\hline Sizes of oil fields (MMBO) & 0.5 & 0.7 & 10 & 0.92 \\
\hline Sizes of gas fields (BCFG) & 3 & 6 & 10 & 6.1 \\
\hline AU probability & 1.0 & & & \\
\hline $\begin{array}{c}\text { North Eromanga Basin Mesozoic } \\
\text { Conventional Reservoirs AU }\end{array}$ & Minimum & Median & Maximum & $\begin{array}{l}\text { Calculated } \\
\text { mean }\end{array}$ \\
\hline Number of oil fields & 1 & 25 & 72 & 26.5 \\
\hline Number of gas fields & 1 & 6 & 18 & 6.4 \\
\hline Sizes of oil fields (MMBO) & 0.5 & 0.7 & 2 & 0.75 \\
\hline Sizes of gas fields (BCFG) & 3 & 5 & 8 & 5.1 \\
\hline AU probability & 1.0 & & & \\
\hline $\begin{array}{l}\text { Greater Nappamerri Trough Permian } \\
\text { Conventional Reservoirs AU }\end{array}$ & Minimum & Median & Maximum & $\begin{array}{l}\text { Calculated } \\
\text { mean }\end{array}$ \\
\hline Number of gas fields & 1 & 30 & 60 & 30.7 \\
\hline Sizes of gas fields (BCFG) & 3 & 9 & 100 & 11.8 \\
\hline AU probability & 1.0 & & & \\
\hline $\begin{array}{c}\text { Greater Patchawarra Trough Permian } \\
\text { Conventional Reservoirs AU }\end{array}$ & Minimum & Median & Maximum & $\begin{array}{l}\text { Calculated } \\
\text { mean }\end{array}$ \\
\hline Number of gas fields & 1 & 10 & 60 & 11.7 \\
\hline Sizes of gas fields (BCFG) & 3 & 9 & 25 & 9.5 \\
\hline AU probability & 1.0 & & & \\
\hline $\begin{array}{l}\text { Queensland Troughs Permian } \\
\text { Conventional Reservoirs AU }\end{array}$ & Minimum & Median & Maximum & $\begin{array}{l}\text { Calculated } \\
\text { mean }\end{array}$ \\
\hline Number of gas fields & 1 & 40 & 144 & 43.5 \\
\hline Sizes of gas fields (BCFG) & 3 & 6 & 25 & 6.7 \\
\hline AU probability & 1.0 & & & \\
\hline
\end{tabular}

Table 2. Assessment results for conventional oil and gas resources in the Eromanga Basin Province, Australia.

[TPS, total petroleum system; AU, assessment unit; MMBO, million barrels of oil; BCFG, billion cubic feet of gas; MMBNGL, million barrels of natural gas liquids. Results shown are fully risked estimates. For gas accumulations, all liquids are included under the NGL (natural gas liquids) category. F95 represents a 95 percent chance of at least the amount tabulated. Other fractiles are defined similarly. Fractiles are additive under the assumption of perfect positive correlation. Shading indicates not applicable]

\begin{tabular}{|c|c|c|c|c|c|c|c|c|c|c|c|c|c|c|}
\hline \multirow{3}{*}{$\begin{array}{c}\text { Total petroleum } \\
\text { system (TPS) and } \\
\text { assessment units (AUs) }\end{array}$} & \multirow{3}{*}{$\begin{array}{l}\text { AU } \\
\text { prob- } \\
\text { ability }\end{array}$} & \multirow{3}{*}{$\begin{array}{c}\text { Accumu- } \\
\text { lation } \\
\text { type }\end{array}$} & \multicolumn{12}{|c|}{ Total undiscovered resources } \\
\hline & & & \multicolumn{4}{|c|}{ Oil (MMBO) } & \multicolumn{4}{|c|}{ Gas (BCFG) } & \multicolumn{4}{|c|}{ NGL (MMBNGL) } \\
\hline & & & F95 & F50 & F5 & Mean & F95 & F50 & F5 & Mean & F95 & F50 & $\mathrm{F} 5$ & Mean \\
\hline \multicolumn{15}{|c|}{ Cooper-Eromanga Composite TPS } \\
\hline \multirow{2}{*}{$\begin{array}{l}\text { South Eromanga Basin } \\
\text { Mesozoic Conventional } \\
\text { Reservoirs AU }\end{array}$} & \multirow[b]{2}{*}{1.0} & Oil & 28 & 46 & 75 & 48 & 48 & 82 & 138 & 86 & 0 & 1 & 1 & 1 \\
\hline & & Gas & & & & & 35 & 61 & 109 & 65 & 1 & 1 & 2 & 1 \\
\hline \multirow{2}{*}{$\begin{array}{l}\text { North Eromanga Basin } \\
\text { Mesozoic Conventional } \\
\text { Reservoirs AU }\end{array}$} & \multirow[b]{2}{*}{1.0} & Oil & 11 & 19 & 33 & 20 & 6 & 12 & 23 & 13 & 0 & 0 & 0 & 0 \\
\hline & & Gas & & & & & 19 & 31 & 54 & 33 & 0 & 0 & 1 & 1 \\
\hline $\begin{array}{l}\text { Greater Nappamerri Trough } \\
\text { Permian Conventional } \\
\text { Reservoirs AU } \\
\end{array}$ & 1.0 & Gas & & & & & 226 & 354 & 540 & 365 & 3 & 5 & 8 & 5 \\
\hline $\begin{array}{l}\text { Greater Patchawarra Trough } \\
\text { Permian Conventional } \\
\text { Reservoirs AU }\end{array}$ & 1.0 & Gas & & & & & 40 & 96 & 244 & 112 & 1 & 3 & 7 & 3 \\
\hline $\begin{array}{l}\text { Queensland Troughs } \\
\text { Permian Conventional } \\
\text { Reservoirs AU }\end{array}$ & 1.0 & Gas & & & & & 135 & 267 & 525 & 290 & 4 & 7 & 15 & 8 \\
\hline $\begin{array}{l}\text { Total undiscovered } \\
\text { conventional resources }\end{array}$ & & & 39 & 65 & 108 & 68 & 509 & 903 & 1,633 & 964 & 9 & 17 & 34 & 19 \\
\hline
\end{tabular}

\section{For More Information}

Assessment results are available at the U.S. Geological Survey Energy Resources Program Web site at http://energy.usgs.gov/.

\section{Eromanga Basin Province Assessment Team}

Christopher J. Schenk, Marilyn E. Tennyson, Tracey J. Mercier, Timothy R. Klett, Thomas M. Finn, Phuong A. Le, Michael E. Brownfield, Stephanie B. Gaswirth, Kristen R. Marra, Sarah J. Hawkins, Heidi M. Leathers-Miller, and Janet K. Pitman 